\title{
The Role of Cyclic Nucleotide Mediators in Latency and Reactivation of HSV-1 Infected Neuroblastoma Cells
}

\author{
ALEJANDRO RODRIGUEZ, MAITE SAINZ DE LA MAZA, JOHN MISSRY, \\ C. STEPHEN FOSTER \\ Boston, Massachusetts, USA
}

\begin{abstract}
Summary
The mechanisms that control herpes simplex virus type 1 latency and reactivation are still poorly understood. We developed an in vitro murine neuroblastoma cell HSV-infected, acyclovir suppressed model to study the influence of different cyclic nucleotide mediators on the latency and reactivation of $\mathrm{HSV}$-1. A positive cDNA 'in situ' hybridisation for HSV genome was used to prove the establishment of a viralhost cell nuclear relationship. An ABC-immunoperoxidase reaction to cell surface HSV mature glycoproteins was also performed to determine the time of viral reactivation with formation of mature virions. Supernates of cultured cells were placed on Vero cells for confirmation of reactivation by classic cytopathic effect. Theophylline $(50 \mu \mathrm{g} / \mathrm{ml})$ and dibutyril-cAMP $(0.1,0.5,1 \mathrm{mg} / \mathrm{ml})$ produced the most pronounced response, accelerating HSV reactivation time by $150 \%$. Epinephrine $(10,20 \mu \mathrm{g} / \mathrm{ml})$ had an intermediate effect on accelerating viral reactivation; and verapamil (20, $50 \mu \mathrm{g} / \mathrm{ml}$ ), theophylline and epinephrine at lower doses had a smaller effect. Carbamylcholine $(10 \mu \mathrm{g} / \mathrm{ml})$ prolonged the time to viral reactivation by $100 \%, 36$ hours compared to control time of 18 hours. Insulin $(0.1,0.5,1 \mathrm{mg} / \mathrm{ml})$ also prolonged HSV 'latency' by six hours. Exogenous dibutyril-cGMP and carbamylcholine at lower concentrations did not have an effect on viral reactivation. These findings suggest that there is a relationship between changes of intracellular concentrations of cyclic nucleotides and HSV latency and reactivation.
\end{abstract}

Latently infected trigeminal ganglia have been thought to be the source of virus for recurrent herpetic keratitis in humans, a major cause of corneal blindness in developed countries. ${ }^{1}$ Current antiviral therapy has proved ineffective in preventing the establishment of latency. The molecular details of the relationship between virus and host cell DNA during the latent state have not been definitely elucidated. ${ }^{2.3}$ An alternative therapeutic strategy to viral DNA elimination from latently infected ganglia might include efforts to indentify and manipulate factors involved in the control of mechanisms responsible for the induction of and reactivation from the latent state. A variety of physiological (fever, trauma, sunburn, menses, stress) and experimental (epinephrine, prostaglandins, ultra-

From: Hilles Immunology Laboratory, Massachuesetts Eye and Ear Infirmary, Harvard Medical School, Boston, MA.

Supported by the Susan Morse Hilles Fund.

Correspondence to: C. Stephen Foster, MD., Hilles Immunology Laboratory, Massachusetts Eye and Ear Infirmary, 243 Charles St, Boston, MA 02114, USA. 
violet light) stimuli can be associated with HSV-1 reactivation in patients and in experimental models respectively. ${ }^{+10}$ These 'triggers' may influence, through the action of first order messengers such as catecholamines and/or arachidonic acid metabolites, cyclic adenosine monophosphate (cAMP) or cyclic guanosine monophosphate (cGMP) concentrations within latently infected neurons. We have already shown in an in vivo and in vitro murine trigeminal ganglion latency model that the relative proportions of intracellular cAMP and cGMP may influence maintenance of (elevated cGMP with no change in cAMP levels) or reactivation from (elevated cAMP) latency. ${ }^{11}$ In order to study further the relationship between intracellular neuronal cyclic nucleotide levels and HSV latency we studied the effects of putative mediators of intracellular cyclic nucleotide levels on an in vitro murine neuroblastoma cell HSVinfected, acyclovir-suppressed model using cDNA 'in situ' hybridisation (viral DNA detection) and avidin-biotin immunoperoxidase (mature virion detection) techniques to determine the time of viral reactivation (positive cDNA 'in situ' hybridisation, positive ABC immunoperoxidase) from 'latency' (positive cDNA 'in situ' hybridisation, negative ABC immunoperoxidase) for each mediator. These findings may have implications for clinical ocular HSV recurrent infections.

\section{Material and Methods}

Cell lines: C-1300 murine neuroblastoma cells (American tissue Culture Collection, Rockville, MD) were cultured using Nutrient Mixture F-12 with L-glutamine media (Gibco Laboratories, Grand Island, NY) supplemented with $5 \%$ qualified fetal bovine serum (FBS) heated and inactivated at $60^{\circ} \mathrm{C}$ for one hour, $5,000 \mathrm{U} / \mathrm{ml}$ of penicillin, $5,000 \mathrm{mcg} / \mathrm{ml}$ of streptomycin (Gibco Labs), $250 \mathrm{mcg} / \mathrm{ml}$ of fungizone (Squibb Flow Labs, Inc., McLean VA), and $250 \mathrm{mg}$ of gentamicin sulfate (Gibco Labs). Vero cells from monkey kidney (CCL81, ATCC) were cultured with Minimum Essential Medium (MEM) with Earle's salts (Gibco Labs), 5\% FBS and penicillin-streptomycin-fungizone-gentamicin solution as above. $75 \mathrm{~cm}^{2}$ sterile cell culture flasks (Becton-Dickinson Labware, Lincoln
Park, $\mathrm{NJ}$ ) were used to grow and maintain the cell lines in an incubator at $37^{\circ} \mathrm{C}$ and $5 \% \mathrm{CO}_{2}$ during the experiments.

Mediators: Mediators that increase intracellular levels of cAMP: N6-2'-O-dibutyriladenosine 3',5' cyclic 'monophosphate sodium salt (purity $=97 \%$ ) (Sigma, St Louis, MO), epinephrine (Elkins-Sinn, Inc., Cherry Hill, $\mathrm{NJ}$ ), isoproterenol $\mathrm{HCl}$ (Winthrop-Beron Lab, New York, NY), theophylline (ElkinsSinn, Inc.) and verapamil $\mathrm{HCl}$ (Knoll Pharmaceuticals, Whippany, $\mathrm{NJ}$ ). Mediators that increase intracellular levels of cGMP: N2,2'O-dibutyrilguanosine $3^{\prime \prime} 5^{\prime}$ cyclic monophosphate sodium salt (purity-96\%) (Sigma), carbamylcholine (Alcon Inc., Humacao, Puerto Rico) and regular recombinant-DNA insulin (Eli Lilly and Co., Indianapolis, IN). Other mediators used: sodium cromoglycate (Fisons Corp., Bedford, MA), dexamethasone sodium phosphate (Elkins-Sinn, Inc.), cyclosporin A (Sandoz, Pharmaceutical Corp., East Hanover, NJ). ${ }^{12}$

Experiment design: Neuroblastoma cells were trypsinised and plated into 6-well, $9.62 \mathrm{~cm}^{2}$ flat bottom tissue culture plates (BectonDickinson Labware) containing a $10.5 \times 22 \mathrm{~mm}$ Thermanox tissue culture plastic coverslip (Miles Lab Inc., Naperville, Il). Each experiment was performed with its own set of controls and was replicated at least four times to demonstrate the reproducibility of the results.

HSV-1 infection of neuroblastoma cells: After three days of cell incubation of $37^{\circ} \mathrm{C}, 5 \% \mathrm{CO}_{2}$, the cultures were infected with $1 \mathrm{ml} /$ well of HSV-1 KOS strain (titer $=2 \times 10^{8} \mathrm{PFU} / \mathrm{ml}$, from Dr David Knipe, Harvard Medical School, Boston, MA) diluted with FBS Nutrient Mixture F0-12 to an MOI of 2, for one hour. The viral suspension was then removed and the wells were washed and rinsed three times with FBS Nutrient Mixture F-12 followed by a post-infection incubation period of six hours with 5\% FBS Nutrient Mixture F-12.

Suppression of HSV-1 with acyclovir: After the post-infection incubation period, the HSV-1 infected neuroblastoma cells were 
treated with $10 \mu \mathrm{g} / \mathrm{ml}$ of acyclovir (ACV) (Burroughs-Welcome, Res. Triangle Park, NC) and $1 \mu \mathrm{g} / \mathrm{ml}$ of $7 \mathrm{~S}$-Nerve Growth Factor (7S-NGF) (Collaborative Research Inc., Bedford, MA) everyday for four days to induce suppression of HSV-1. ${ }^{13}$ At the end of day four, the cells were washed and rinsed three times with FBS Nutrient Mixture F-12 to remove the $\mathrm{ACV} / 7 \mathrm{~S}-\mathrm{NGF}$ solution.

Time-course for detection of $H S V-1$ reactivation time: Cyclic nucleotide mediators at different doses were then added to the HSV-infected, ACV-suppressed neuroblastoma cells. Preliminary dose-response studies (unreported) were performed to determine the mediator toxicity limits. A time-course consisting of the removal of the supernate and a set of coverslips every two hours for cocultivation on Vero cells ${ }^{1+}$ and immunohistochemical staining respectively was done. The time course was 48 to 72 hours depending on the type of mediator used.

Controls: These consisted of neuroblastoma cells on coverslip without HSV infection and without ACV/7S-NGF (positive-control); and a set of coverslips HSV-infected, ACVsuppressed, incubated with fresh culture media and nerve growth factor $(1 \mu \mathrm{g} / \mathrm{ml})$ alone, which were withdrawn along with the mediator coverslips during every time-course (model control).

cDNA 'in situ' hybridisation: Withdrawn coverslips were left to dry at room temperature for at least two days and then stained with an HSV cDNA probe assay (ENZO Diagnostics, Inc., New York, NY). Thermanox coverslips were cut into two equal pieces; one was used for the $\mathrm{ABC}$ immunoperoxidase stain; the other was rinsed with PBS ( $\mathrm{pH} 7.2)$ and fixed with $100 \%$ acetone for 10 minutes. One drop of the DNA probe reagent was then applied to each Thermanox tissue culture coverslip and a glass coverslip was then placed to cover the preparation which was then placed onto a $92^{\circ} \mathrm{C}$ heating block for 3-4 minutes. After removing the coverslip from the block, hybridisation proceeded at room temperature for 20 minutes in a moisture chamber. The post-hybridisation reagent was applied for 10 minutes after removal of the glass coverslip. The coverslips were rinsed with wash buffer for 10 seconds and the detection reagent (avidinbiotinylated horseradish peroxidase) was applied for 10 minutes. The coverslips were rinsed with wash buffer, counterstained with fast green FCF and mounted with gelvatol for light microscopy.

$A B C$ immunoperoxidase staining: The other half of the coverslip was also rinsed in PBS $(\mathrm{pH} 7.2)$ and fixed with acetone as above. Coverslips were incubated with a $5 \%$ normal goat serum solutions for 30 minutes. A rabbit anti-HSV-1 antibody (IgG anti-HSV, Dako Corp., Santa Barbara, CA) was diluted to $1: 100$ with $1 \%$ BSA, filtered with a $0.2 \mu \mathrm{m}$ microfilter (Gelman Sciences Inc., Ann Arbor, MI) and absorbed with neuroblastoma cells for 15 minutes on a rotating table. A further dilution to $1: 1600$ with $1 \%$ BSA and centrifugation with $2800 \mathrm{rpm}$ for 10 minutes at $25^{\circ} \mathrm{C}$ was followed by adding it to the coverslips for 45 minutes (primary incubation) at room temperature in a moisture chamber. The coverslips were then rinsed three times with $\mathrm{PBS}\left(\mathrm{pH}\right.$ 7.2) for 10 minutes. $\mathrm{H}_{2} \mathrm{O}_{2}$ $0.3 \%$, was added to each coverslip for $30 \mathrm{~min}$ utes. A rabbit $\mathrm{ABC}$ Vectastain kit (Vector Laboratories Inc., Burlingame, CA) was then used to follow the staining. The secondary incubation was performed after rinsing the coverslip; one drop of goat anti-rabbit $\operatorname{IgG}$ biotinylated antibody was applied for $45 \mathrm{~min}$ utes, followed by a rinse with PBS. The tertiary 45 minute incubation with the avidin-biotinylated peroxidase was performed before reacting the coverslips with the aminoethycarbazole substrate for 20 minutes. Coverslips were rinsed with acetate buffer ( $\mathrm{pH} \mathrm{5.0)}$ and fixed with $4 \%$ formaline; $1 \%$ glacial acetic acid was applied before counterstaining with Gill's hematoxylin and mounting with gelvatol for light microscopy.

Cocultivation of supernates on Vero cells: All supernates from the time-course (mediator samples and controls) coverslips were filtered and placed on confluent monolayers of Vero cells and observed daily for 10 days, using an inverted light microscope for cytopathic effect (CPE). 


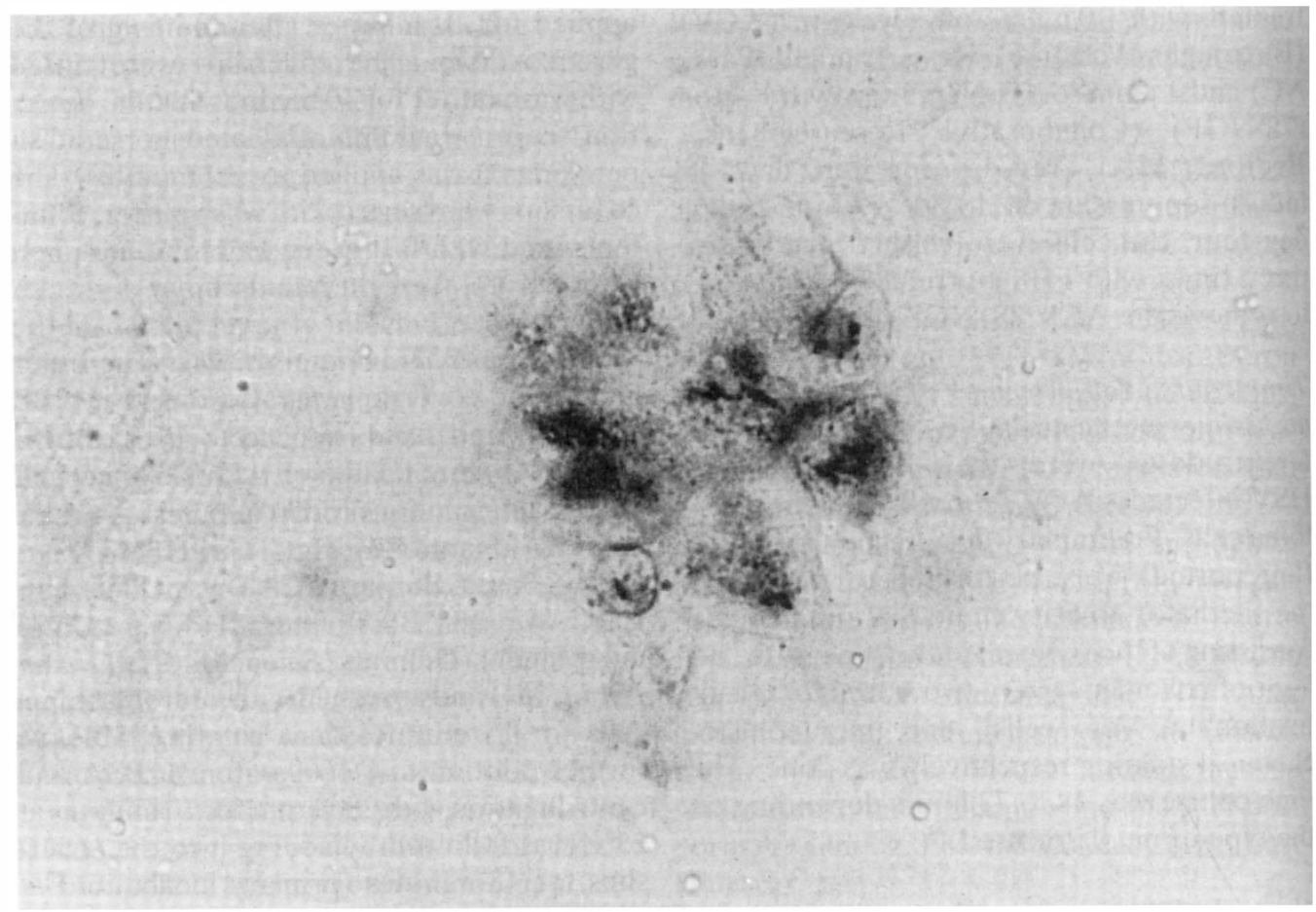

Fig. 1. Positive $c D N A$ 'in situ' hybridisation for HSV in HSV-1 infected neuroblastoma cells $(40 \times)$

Statistics: Differences in time for HSV-1 reactivation (positive ABC immunoperoxidase staining) for each mediator compared to control were analysed using the Analysis of Variance test $(p<0.05)$.

\section{Results}

A positive cDNA 'in situ' hybridisation for HSV was a consistent finding in all coverslips containing HSV-1 infected neuroblastoma

Table 1. Percentage of neuroblastoma cells infected with HSV-1 as shown by a positive cDNA 'in situ' hybridisation for HSV using different multiplicities of infection (MOI)

\begin{tabular}{lc}
\hline MOI & $\begin{array}{c}\text { cDNA positive cells } \\
(\text { Mean count }+ \text { SEM) }\end{array}$ \\
\hline 1 & $13.04+1.712$ \\
2 & $21.40+2.831$ \\
4 & $43.12+2.796$ \\
5 & $45.32+5.103$ \\
6 & $52.54+4.995$ \\
8 & $49.38+3.692$ \\
10 & $73.58+4.441$ \\
\hline
\end{tabular}

*Cell count of $5(450 \times)$ power fields of 2 coverslips per MOI using a $10 \times 10 \mathrm{~mm}$ grid. cells, showing the establishment of a viralhost cell genome relationship (Fig. 1). The percentage of cells showing a positive cDNA stain correlated directly with the MOI used (Table I). HSV-1 infected neuroblastoma cells treated with NGF and ACV also showed, consistently, cDNA positive cells for HSV DNA while, at the same time, manifesting no mature, late (gamma) HSV proteins. Supernatants from these cultures consistently failed to yield infectious virions when cultured on Vero cells; supernatants from such cultures not treated with experimental mediators were HSV negative for 18 hours after removal of ACV from the culture medium (desuppression).

The results show that the mean HSV reactivation time from an acyclovir-induced 'latency' in neuroblastoma cells was 18 hours (positive $\mathrm{ABC}$ immunoperoxidase reaction) after the withdrawal of the ACV-7S-NGF solution (Fig. 2). This finding was consistent throughout the different sets of experimentse Cultivation of supernates on vero cells produced CPE due to mature HSV. This tra- 


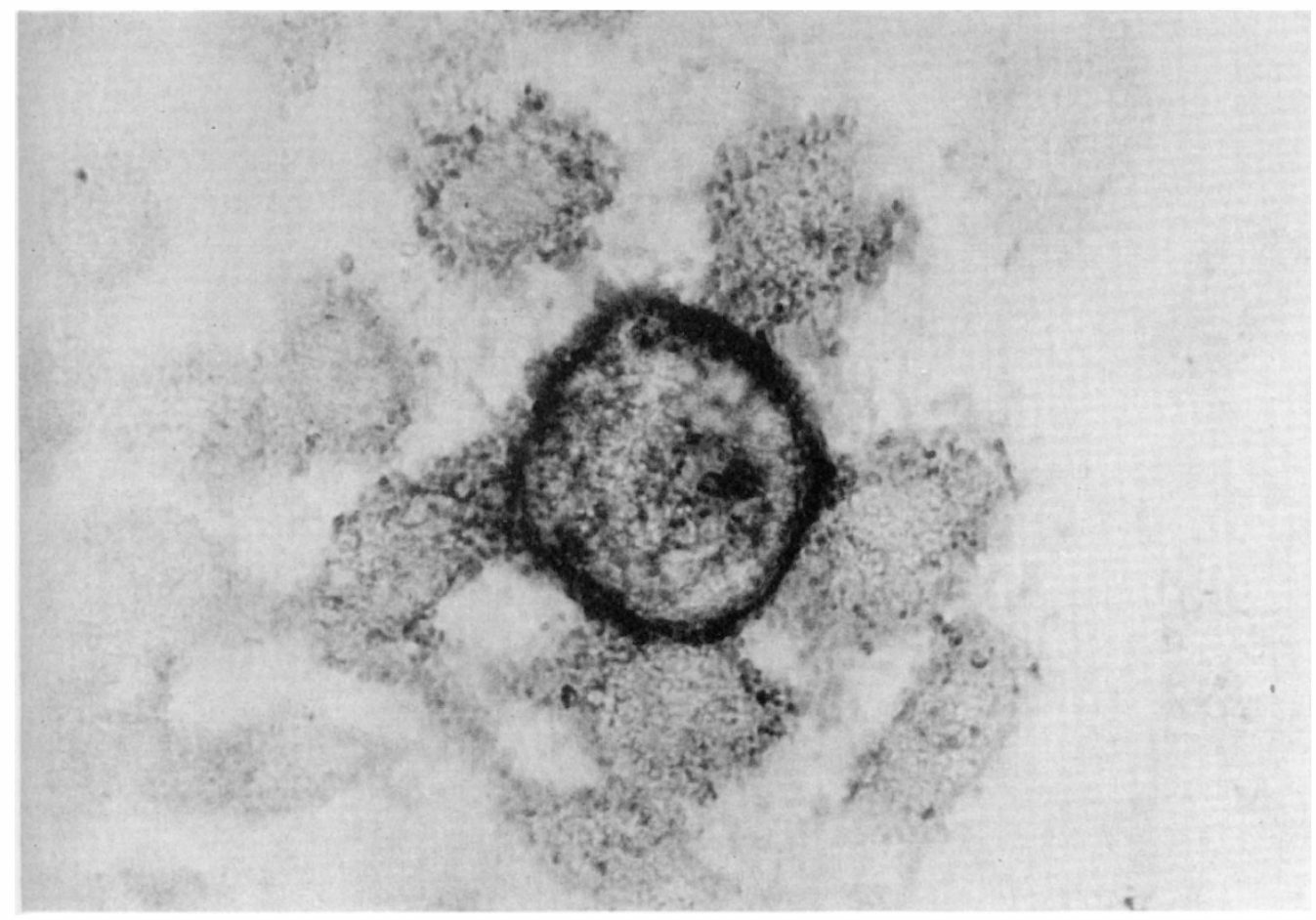

Fig. 2. Positive ABC-immunoperoxidase staining for anti-HSV-1 antibody in HSV-1 reactivation from an acyclovir-induced 'latency' in neuroblastoma cells $(100 \times)$

ditional assay, however, was clearly less sensitive and less precise than was the $A B C$ assay for HSV gamma proteins. The mean time to $\mathrm{HSV}$ reactivation following withdrawal of ACV as determined by supernate HSV positivity was 24 hours (Table II).

Of the cyclic nucleotide mediators that increase the intracellular levels of cAMP (Table II), the phosphodiesterase inhibitor theophylline $(50 \mu \mathrm{g} / \mathrm{ml})$ and dibutyril-cAMP
$(0.1,0.5,1 \mathrm{mg} / \mathrm{ml})$ produced the most pronounced acceleration of the reactivation time of HSV-1, six hours compared to the controls' mean reactivation time of 18 hours $(\mathrm{p}<0.05)$.

Epinephrine $(10,20 \mu \mathrm{g} / \mathrm{ml})$, an adrenergic agonist, accelerated the reactivation of HSV-1 by eight hours (mean time to reactivation, 10 hours; control reactivation time, 18 hours) $(\mathrm{p}<0.05)$ (Fig. 3).

Lower concentrations of theophylline (10,

Table II. Effect of cyclic nucleotide mediators that increase intracellular levels of cAMP in viral reactivation of HSV-1 infected neuroblastoma cells

\begin{tabular}{lccc}
\hline Mediator & \multicolumn{2}{c}{ Reactivation time } & (hours) \\
& $+A B C$ & $+C P E$ & Dose \\
\hline Dibutyril-cAMP & $6^{*}$ & 6 & $0.1,0.5,1 \mathrm{mg} / \mathrm{ml}$ \\
Theophylline & $6^{*}$ & 12 & $50 \mu \mathrm{g} / \mathrm{ml}$ \\
& $12^{*}$ & 24 & $10,20 \mu \mathrm{g} / \mathrm{ml}$ \\
Epinephrine & $10^{*}$ & 18 & $10,20 \mu \mathrm{g} / \mathrm{ml}$ \\
Verapamil & $12^{*}$ & 18 & $5 \mu \mathrm{g} / \mathrm{ml}$ \\
& $12^{*}$ & 12 & $20,50 \mu \mathrm{g} / \mathrm{ml}$ \\
Isoproterenol & 18 & 18 & $10 \mu \mathrm{g} / \mathrm{ml}$ \\
Controls & 18 & 24 & $2.5,5,10 \mu \mathrm{g} / \mathrm{ml}$ \\
\hline
\end{tabular}

Significant values on the $\mathrm{ABC}$ immunoperoxidase staining using Analysis of Variance test $(\mathrm{P}<0.05)$. 


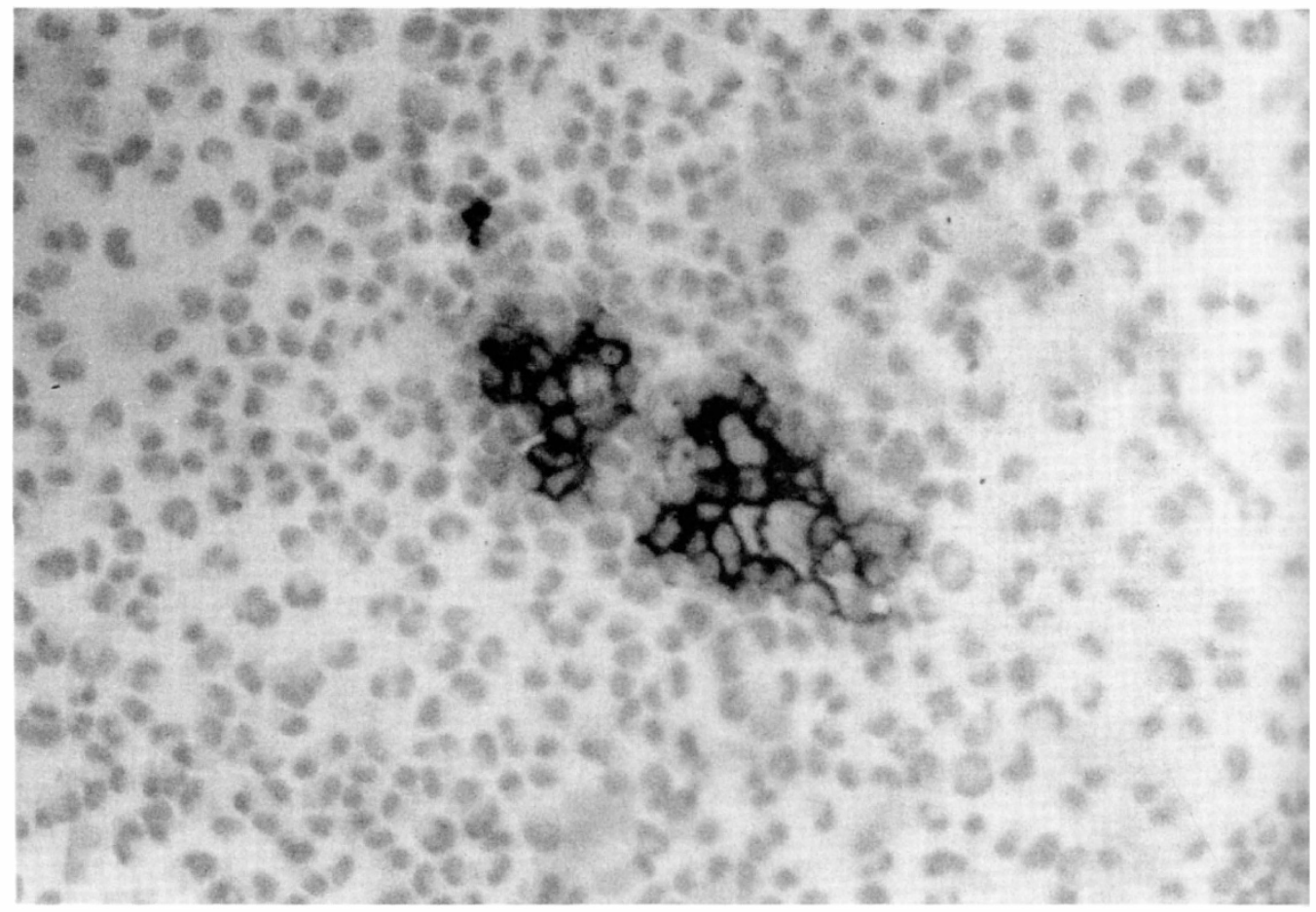

Fig. 3. Positive ABC-immunoperoxidase staining for anti-HSV-1 antibody in HSV-1 infected, acyclovir suppressed neuroblastoma cells after 12 hours with Epinephrine $20 \mu \mathrm{g} / \mathrm{ml}(16 \times)$.

$20 \mu \mathrm{g} / \mathrm{ml})$, epinephrine $(5 \mu \mathrm{g} / \mathrm{ml})$ and the calcium channel blocker, verapamil $(20,50 \mu \mathrm{g} /$ $\mathrm{ml})$ which has a demonstrated phosphodiesterase inhibitor activity, ${ }^{15}$ had a smaller effect, inducing HSV-1 reactivation six hours before the controls $(\mathrm{p}<0.05)$.

Verapamil at lower dose $(10 \mu \mathrm{g} / \mathrm{ml})$ and isoproterenol $(2.5,5,10 \mu \mathrm{g} / \mathrm{ml})$, a beta adrenergic agonist, had no demonstrable effect on the induction of HSV-1 reactivation in this model.

Of the mediators that increase intracellular levels of cGMP by activation of the guanylate cyclase system (Table III), the most stable synthetic metabolite of acetylcholine, carbamylcholine $(10 \mu \mathrm{g} / \mathrm{ml})$, a muscarinic cholinergic agonist, showed the most pronounced effect in prolonging the 'latency' of HSV-1 in neuroblastoma cells by doubling the time of reactivation compared to controls $(\mathrm{p}<0.05)$ Fig. 4).

Insulin $(0.1,0.5,1 \mathrm{U} / \mathrm{ml})$ also prolonged the reactivation time of HSV-1 by six hours compared to controls $(\mathrm{p}<0.05)$ (Fig. 5).

Carbamylcholine at a lower dose $(5 \mu \mathrm{g} / \mathrm{ml})$

Table III. Effect of cyclic nucleotide mediators that increase intracellular levels of cGMP in prolonging the latency of HSV-1 infected neuroblastoma cells

\begin{tabular}{lccc}
\hline Mediator & \multicolumn{2}{c}{ Reactivation time } & (hours) \\
& $+A B C$ & $+C P E$ & Dose \\
\hline Dibutyril-cGMP & 18 & 24 & $0.1,0.5,1 \mathrm{mg} / \mathrm{ml}$ \\
Carbamylcholine & $36^{*}$ & 48 & $10 \mu \mathrm{g} / \mathrm{ml}$ \\
& 18 & 24 & $5 \mu \mathrm{g} / \mathrm{ml}$ \\
Insulin & $24^{*}$ & 48 & $0.1,0.5,1 \mathrm{U} / \mathrm{ml}$ \\
Controls & 18 & 24 & \\
\hline
\end{tabular}

*Significant values on the ABC immunoperoxidase staining using Analysis of Variance test $(\mathrm{P}<0.05)$. 


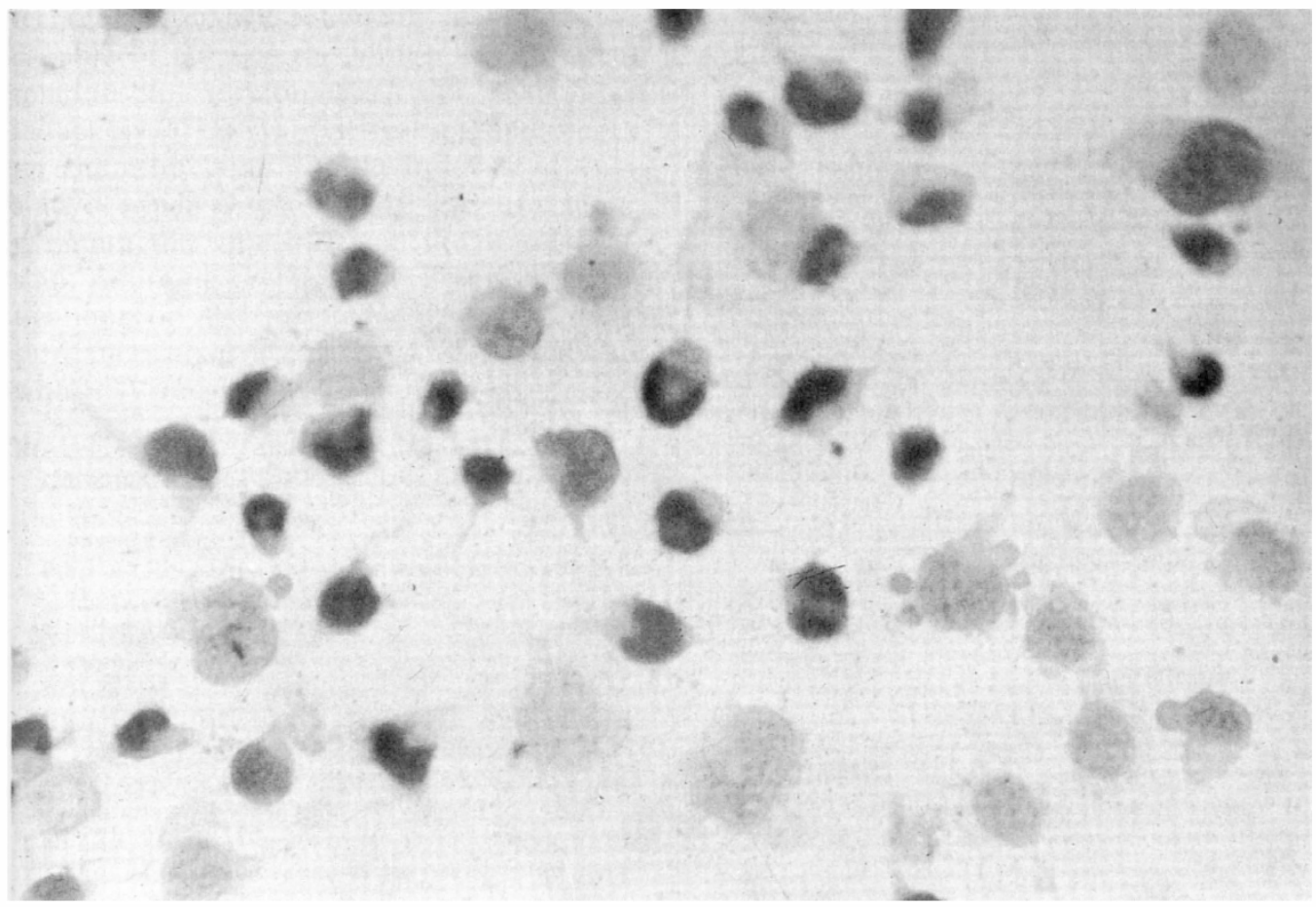

Fig. 4. Negative ABC-immunoperoxidase staining for anti-HSV-1 antibody in HSV-1 infected, acyclovir suppressed neuroblastoma cells after 18 hours with Carbamylcholine $10 \mu \mathrm{g} / \mathrm{ml}(25 \times)$.

and dibutyril-cGMP (0.1, $0.5,1 \mathrm{mg} / \mathrm{ml})$ showed no effect on prolonging the 'latency' of HSV-1 in this neuroblastoma cell model.

Cyclosporine at low doses $(1,2.5,5 \mu \mathrm{g} / \mathrm{ml})$ due to its high toxicity on neuroblastoma cells induced viral reactivation moderately compared to controls (Table IV).

Dexamethasone phosphate $(20 \mu \mathrm{g} / \mathrm{ml})$ and sodium cromoglycate $(25 \mu \mathrm{g} / \mathrm{ml})$ did not have an effect in inducing reactivation or prolonging the latent state of HSV-1.

\section{Discussion}

Recurrences of ocular HSV are related to the well known cycle of latent trigeminal ganglionic infection, ganglionic viral reactivation. and ocular virus shedding. ${ }^{4-10,12-15}$ Despite the recent advances into the nature of HSV latency, little is known about the mechanisms of HSV-1 latency and reactivation. Therefore there are no clinically reliable methods of preventing the establishment of latent infection of the trigeminal ganglion, of inhibiting ganglionic viral reactivation, or of preventing viral shedding. An alternative strategy for preventing the cumulative permanent structural alterations of the eye which compromise vision is to manipulate the physiologic changes which control HSV latency and reactivation. If latency is controlled by the expression of certain genes not expressed during lytic infection, how can these genes be activated? If latency is controlled by the lack of expression of certain genes, how can these genes be blocked? If reactivation is the suppression of the mechanisms maintained during latency, how can this suppression be inhibited? It has been shown that regulation of cellular responsiveness to cAMP may be regulated at multiple biochemical levels that can clearly affect the macromolecular processes involved in gene expression, which in turn may lead to stimulation of cellular differentiation ${ }^{16}$ or proliferation. $^{17,18}$ Similarly in HSV-1 infection, biochemical signals generated at the host plasma membrane by ligand receptor-coupled 'second messenger' (cAMP or cGMP) could foster the expression of specific genes fundamental in the initiation and maintenance of 


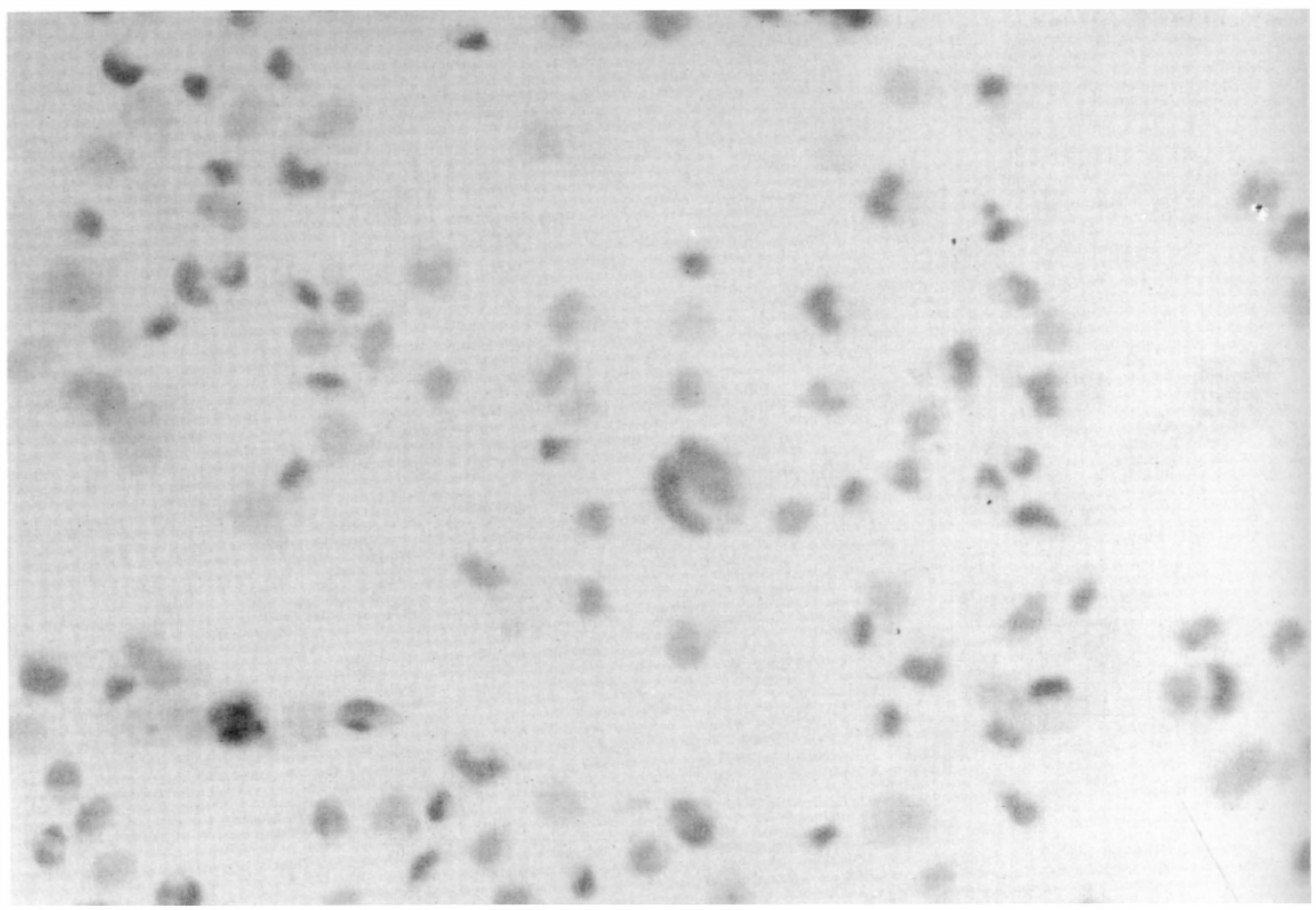

Fig. 5. Negative ABC-immunoperoxidase staining for anti-HSV-1 antibody in HSV-I infected, acyclovir suppressed neuroblastoma cells after 18 hours with Insulin $1 \mathrm{U} / \mathrm{ml}(16 \times)$.

HSV-1 latency or induction of reactivation. Recent studies on latency show that latencyassociated transcripts (LATs), although not essential for establishment or reactivation of viral latency, may play a role in the efficiency of reactivation in vitro. ${ }^{19}$ It has been suggested that LATs expression may be inducible by extracellular signals through a pathway involving the cAMP dependent protein kinase. ${ }^{20}$ We have previously shown that C-1300 (CCL147) neuroblastoma cells respond to different cyclic nucleotide mediators by altering the intracellular levels of cAMP and cGMP. ${ }^{11}$ We have also shown in an in vivo/in vitro murine trigeminal ganglion latency model that first order messenger mediated modulation of ganglionic cyclic nucleotide concentrations is associated with perturbations in the viral DNA-host DNA relationship. Elevation in intracellular cGMP concentrations is associated with retardation of HSV reactivation from latency, and elevation of intracellular cAMP levels is associated with provocation of HSV reactivation. ${ }^{11} \mathrm{We}$ now report, in an effort to develop a more sensitive and accurate method for measuring the time for reactivation, the results of cDNA 'in situ' hybridisation and $\mathrm{ABC}$ immunoperoxidase reaction during latency and reactivation in an in vitro murine neuroblastoma cell latency model. We find once again, in yet another latency model and using molecular

Table IV. Effect of other compounds in viral reactivation and latency in HSV-I infected neuroblastoma cells

\begin{tabular}{lccc}
\hline Mediator & \multicolumn{2}{c}{ Reactivation time } & $($ hours $)$ \\
& $+A B C$ & $+C P E$ & Dose \\
\hline Cyclosporine & 12 & 12 & $1,2.5,5 \mathrm{mg} / \mathrm{ml}$ \\
Dexamethasone & 18 & 24 & $20 \mu \mathrm{g} / \mathrm{ml}$ \\
Cromoglycate & 18 & 24 & $25 \mu \mathrm{g} / \mathrm{ml}$ \\
Controls & 18 & 24 & \\
\hline
\end{tabular}


techniques, cAMP enhancing mediators are capable of altering the viral-host cell latent relationship resulting in the accelerated induction of $\mathrm{HSV}$ reactivation and hence recurrent infection. On the other hand, substances which elevate cGMP in neural tissue maintain the viral-host cell latent relationship, retarding reactivation. Potential investigations on the prophylactic use of these substances open new perspectives for patients with HSV recurrent infections.

\section{References}

${ }^{1}$ Dawson CR and Tongi B: Herpes simplex eye infections: Clinical manifestations, pathogenesis and management. Surv Ophthalmol 1976;21: 121-30.

${ }^{2}$ Puga A, Rosenthal JD, Openshaw H, Notkins AL: Herpes simplex virus DNA and mRNA sequences in acutely and chronically infected trigeminal ganglia of mice. Virology 1978, 89: 102-111.

${ }^{3}$ Efstathiou S, Minson AC, Field HJ, Anderson JR, Widly P: Detection of herpes simplex virus specific DNA sequences in latently infected mice and in humans. J Virol 1986, 57: 446-55.

${ }^{+}$Hill TJ, Blyth WA, Harbour DA: Trauma to the skin causes recurrence of herpes simplex in the mouse. J Gen Virol 1978, 39: 21-8.

${ }^{5}$ Green MT, Rosborough JP, Dunkel EC: In vivo reactivation of herpes simplex virus in rabbit trigeminal ganglia: electrode model. Infect Immun 1981, 34: 69-74.

${ }^{6}$ Willey DE, Trousdale MD, Nesburn AB: Reactivation of murine latent HSV infection by epinephrine iontophoresis. Invest Ophthalmol Vis Sci 1984, 25: 945-50.

${ }^{7}$ Hill JM, Rayfield MA, Haruta Y: Strain specificity of spontaneous and adrenergically induced HSV-1 ocular reactivation in latently infected rabbits. Curr Eye Res 1987, 6: 91-6.

${ }^{8}$ Kwon BS, Gangarosa LP, Burch KD, de Back J, Hill JM: Induction of ocular herpes virus shedding by iontophoresis of epinephrine into rabbit cornea. Invest Ophthalmol Vis Sci 1981, 21: 442-9.

${ }^{9}$ Blyth WA, Hill TF, Field HJ, Harbour DA: Reactivation of herpes simplex virus infection by ultraviolet light and possible involvement of prostaglandins. J Gen Virol 1976, 33: 547-50.
${ }^{10}$ Harbour DA, Hill TJ, Blyth WA: Recurrent herpes simplex in the mouse: inflammation in the skin and activation of virus in the ganglia following peripheral stimulation. J Gen Virol 1983, 64: 1491-8.

${ }^{11}$ Sainz de la Maza M, Wells PA, Foster CS: Cyclic nucleotide modulation of herpes simplex virus latency and reactivation. Invest Ophthalmol Vis Sci 1989, 30: 2154-9.

${ }^{12}$ Cook ML, Bastone VB, Stevens JG: Evidence that neurons harbor latent herpes simplex virus. Infect Immun 1974, 9: 946-51.

${ }^{1.3}$ McLennan JL and Darby G: Herpes simplex virus latency: The cellular location of virus in dorsal root ganglia and the fate of the infected cell following virus activation. J Gen Virol 1980, 51: 233-43.

${ }^{14}$ Stevens JG: Latent herpes simplex virus and the nervous system. Curr Top Microbiol Immunol 1975, 70: $31-40$.

${ }^{15}$ Field $\mathrm{HJ}$ and De Clercq E: Effects of oral treatment with acyclovir and bromovinyldeoxyuridine on the establishment and maintenance of latent herpes simplex virus infection in mice. J Gen Virol 1981, 56: 259-65.

${ }^{16}$ Heidemann SR, Joshi HC, Schechter A, Fletcher JR, Bothwell M: Synergistic effects of cyclic AMP and nerve growth factor on neurite outgrowth and microtubule stability of $\mathrm{PC} 12$ cells. J Cell Biol 1985, 100: 916-27.

${ }^{17}$ Tramontano D, Chin WW, Moses AC, Ingbar SH: Thyrotropin and dibutyrylcyclic AMP increase levels of c-myc and c-fos mRNAs in cultured rat thyroid cells. J Biol Chem 1986, 261: 3919-22.

${ }^{18}$ Ran W, Dean M, Levin RA, Henkle C, Campisis J: Induction of c-fos and c-myc mRNA by epidermal growth factor or calcium ionophore is cyclic AMP dependent. Proc Natl Acad Sci USA 1986, 83: 8216-20.

${ }^{19}$ Leib DA, Bogard CL, Kosz-Vnenchak M, Hicks KA, Coen DM, Knipe DM, Shaeffer PA: A deletion mutant of the latency-associated transcript of herpes simplex virus type 1 reactivates from the latent state with reduced frequency. J Virol 1989 , 63: $2893-900$.

${ }^{210}$ Leib DA, Nadeau KC, Rundle SA, Schaeffer PA: Promoter of the latency associated transcripts of HSV type 1 contains a functional cAMP response element: role of the latency associated transcripts and cAMP in reactivation of viral latency. Proc Natl Acad Sci USA 1991, 88: 48-52. 